\title{
The tumor suppressor miR-138-5p targets PD-L1 in colorectal cancer
}

\author{
Lian Zhao ${ }^{1,2}$, Haibo Yu ${ }^{3}$, Shuijing $\mathrm{Yi}^{4}$, Xiaowei Peng ${ }^{5}$, Peng Su ${ }^{1,2}$, Zhiming Xiao ${ }^{1}$, Rui \\ Liu $^{1}$, Anliu Tang ${ }^{1,2}$, Xiayu Li ${ }^{1,2}$, Fen Liu ${ }^{1,2}$, Shourong Shen ${ }^{1,2}$ \\ ${ }^{1}$ Department of Gastroenterology, The Third Xiangya Hospital, Central South University, Changsha, Hunan, China \\ ${ }^{2}$ Hunan Key Laboratory of Nonresolving Inflammation and Cancer, Changsha, Hunan, China \\ ${ }^{3}$ Department of Metabolism and Endocrinology, The Second Xiangya Hospital, Central South University, Changsha, Hunan, \\ China \\ ${ }^{4}$ Department of Gynaecology and Obstetrics, The Third Xiangya Hospital, Central South University, Changsha, Hunan, China \\ ${ }^{5}$ Department of Breast Oncology Plastic and Head and Neck, The Affiliated Cancer Hospital of Xiangya Medical School, \\ Hunan, China
}

Correspondence to: Haibo Yu, email: yuhaibo616@163.com

Keywords: miR-138-5p, PD-L1, tumor suppressor, colorectal cancer, biomarker

Received: August 21, $2015 \quad$ Accepted: May 13, 2016

Published: May 27, 2016

\section{ABSTRACT}

microRNAs (miRNAs) play critical roles in cancer development and progression. This study investigated the effects of miR-138-5p in human colorectal cancer (CRC) development. miR-138-5p was frequently downregulated in CRC tissues and was associated with advanced clinical stage, lymph node metastasis and poor overall survival. We found that miR-138-5p decreased expression of programmed cell death ligand 1 (PD-L1) through interaction with its PD-L1 3' untranslated region. miR-138$5 p$ also dramatically suppressed CRC cell growth in vitro and inhibited tumorigenesis in vivo. PD-L1 and miR-138-5p levels were inversely correlated in human CRC tumors, and miR-138-5p inhibited PD-L1 expression in tumor models. These results suggest that miR-138-5p is a tumor suppressor in CRC, and its effects are exerted at least partially through PD-L1 downregulation. Low miR-138-5p and high PD-L1 levels correlated with shorter overall CRC patient survival, indicating that miR-138-5p and PD-L1 may serve as CRC biomarkers for risk group assignment, optimal therapy selection and clinical outcome prediction. Targeting PD-L1, possibly by administering miR-138-5p mimics, might be a clinically effective anti-CRC therapeutic strategy.

\section{INTRODUCTION}

$\mathrm{CRC}$ is one of the most common malignancies in the world and is the second leading cause of cancer-related mortality in Western countries [1]. Efforts to elucidate the underlying causes of CRC and to develop more effective therapies have thus far met with only limited success [2]. microRNAs (miRNAs) belong to a class of short, highly conserved non-coding RNAs known to suppress protein coding gene expression through imperfect base pairing with the 3'untranslated regions (UTRs) of target messenger RNAs (mRNAs) [3]. miRNAs have been implicated in the control of various biological processes, such as cell proliferation, apoptosis and differentiation [4-7]. Alterations in miRNA expression have been observed in CRC, and several dysregulated miRNAs, including miR-625-3p [8], miR-99-5b [9], miR-361-5p [10], miR-17-5p [11], miR-137 [12], miR-95 [13], miR23a [14, 15], miR-155 [16], miR-150 [17], miR-191[18], miR-339-5p [19], miR-429 [20], miR-345 [21], miR-22 [22], miR-638 [23] and miR-138 [24], have been shown to regulate $\mathrm{CRC}$ cell growth, apoptosis and metastasis. However, the role of miRNAs in CRC development and progression remains unclear, and more extensive studies are required to identify those miRNAs that may be useful as prognostic predictors and/or therapeutic targets in CRC.

PD-L1 is constitutively activated in tumor cells, promoting tumor survival and growth by increasing the capacity of tumors to evade the immune system [25-31]. Furthermore, PD-L1 was reported as an oncogene that 
correlates with poor prognosis in several carcinomas [32-35]. In this study, miR-138-5p was shown to be frequently downregulated in CRC tissues and might act as a tumor suppressor. We found that miR-138-5p markedly suppressed CRC cell growth in vitro and inhibited tumorigenesis in vivo by targeting PD-L1; miR-138-5p expression was inversely correlated with that of PD-L1 in CRC. Low miR-138-5p expression was associated with advanced clinical stage, lymph node metastasis and poor overall patient survival, and high PD-L1 expression correlated with decreased overall patient survival.

\section{RESULTS}

\section{miR-138-5p is frequently downregulated in CRC}

miR-138-5p expression was measured in $21 \mathrm{CRC}$ samples and corresponding adjacent normal tissues by qRT-PCR. miR-138-5p downregulation was detected in 19/21 (90.48\%) of CRC tumors (Figure 1A). Average miR-138-5p expression was approximately 2.3-fold lower in CRC specimens as compared with corresponding adjacent normal tissues $(P<0.05$, Figure $1 \mathrm{~B})$. miR-138$5 \mathrm{p}$ expression was also downregulated in CRC cell lines compared with normal colonic epithelium cell lines (Figure 1C). In situ hybridization (ISH) analysis in 188 CRC samples showed miR-138-5p downregulation in $92 / 188(48.9 \%)$ tumors (Figure 1D). The clinical association analysis found that low miR-138-5p expression was correlated with advanced clinical stage $(P<0.05)$ and lymph node metastasis $(P<0.05$, Table 1$)$. Kaplan-Meier analysis indicated that low miR-138-5p expression was associated with poorer overall survival (log-rank test, $P=0.001$, Figure 1E). Further, multivariate Cox regression analysis revealed that low miR-138-5p expression is an independent prognostic factor for poor survival of CRC patients $(P<0.01$, Table 2$)$.

\section{PD-L1 is a direct miR-138-5p target}

To clarify the relationship between miR-138-5p and PD-L1, basic information about hsa-miR-138$5 \mathrm{p}$ was collected from miRBase. PD-L1 is a putative miR-138-5p target predicted by MIRDB (Figure 2A). To verify PD-L1 targeting by miR-138-5p, reporter constructs in which the PD-L1 3'UTR, either wild type or mutated in the miR-138-5p binding sites, was cloned downstream of the luciferase open reading frame (Figure 2Ab). miR-138-5p mimic and inhibitors were transfected into HCT116, SW620, NCM460 and CCD841CoN cells (Figure 2B). When the PD-L1 3' UTR was attached to the luciferase gene, luciferase activity decreased significantly $(P<0.05)$ in HCT116 and SW620 cells transfected with miR-138-5p mimics, demonstrating that PD-L1 was the target of miR-138$5 \mathrm{p}$ (Figure 2C). Furthermore, expression of mutant PD-
L1 3' UTR restored luciferase activity. To examine the effect of miR-138-5p on endogenous PD-L1 expression, two cell lines with low miR-138-5p expression, HCT116 and SW620, were transfected with miR-138-5p mimics; PD-L1 protein levels were decreased (Figure 2Da). When two cell lines with high miR-138-5p expression, NCM460 and CCD841CoN, were transfected with miR-138-5p inhibitors, PD-L1 levels were increased (Figure 2Db).

\section{miR-138-5p inhibits cell growth and blocks S-phase entry partially through PD-L1 downregulation in vitro}

miR-138-5p was ectopically expressed in CRC cell lines. We determined the effects of miR-138-5p overexpression or inhibition on cell proliferation via MTT assay. HCT116 and SW620 cells (which have low endogenous miR-138-5p expression) transfected with miR-138-5p mimics showed decreased proliferation $(P<0.05)$, which was rescued by overexpression of the target gene, PD-L1 (Figure 3A \& 3C). In HCT116 and SW620 cells transfected with miR-138-5p mimics, the number of cells in $\mathrm{S}$ phase of the cell cycle decreased and the number in $\mathrm{G} 1$ phase increased $(P<0.05$, Figure $3 \mathrm{~B} \&$ $3 \mathrm{D})$, and this was again rescued by PD-L1 overexpression $(P<0.05)$.

PD-L1 small interfering RNA (siRNA) transfected into NCM460 cells reduced PD-L1 protein levels, while the negative control (scramble) had no effect (Figure 4A). NCM460 and CCD841CoN cells (with high endogenous miR-138-5p expression) transfected with miR-138-5p inhibitors showed increased proliferation $(P<0.05)$, and this was rescued by PD-L1 siRNA transfection (Figure 4B \& 4D). In NCM460 and CCD841CoN cells transfected with miR-138-5p inhibitors, the number of cells in $\mathrm{S}$ phase of the cell cycle increased and the number in G1 phase decreased $(P<0.05$, Figure 4C \& 4E); this was rescued by PD-L1 siRNA transfection $(P<0.05)$. Collectively, these results suggest that miR-138-5p expression in CRC cells is important for both proliferation and cell cycle progression, and miR-138-5p acts by downregulating PD-L1.

\section{Ectopic miR-138-5p expression suppresses CRC cell tumorigenicity in vivo}

Two stable cell lines derived from SW620, SW620miR-138-5p and SW620-scramble, were established using LV-miR138-5p and LV-scramble, respectively. SW620-miR-138-5p and SW620-scramble cells were inoculated into mice (four in each group). SW620-miR$138-5$ p cells exhibited significantly reduced tumor growth compared with SW620-scramble cells (Figure 5A\&5B). On day 12, average tumor size in SW620-miR-138-5p mice was reduced as compared to controls $(P<0.05)$. Immunohistochemical (IHC) (Figure 5C) and western blot 


\section{A}

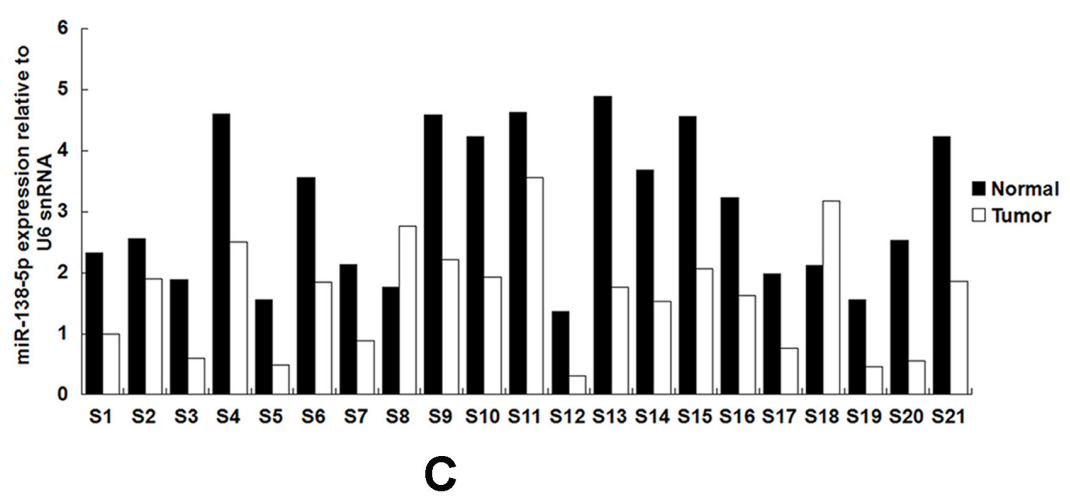

B
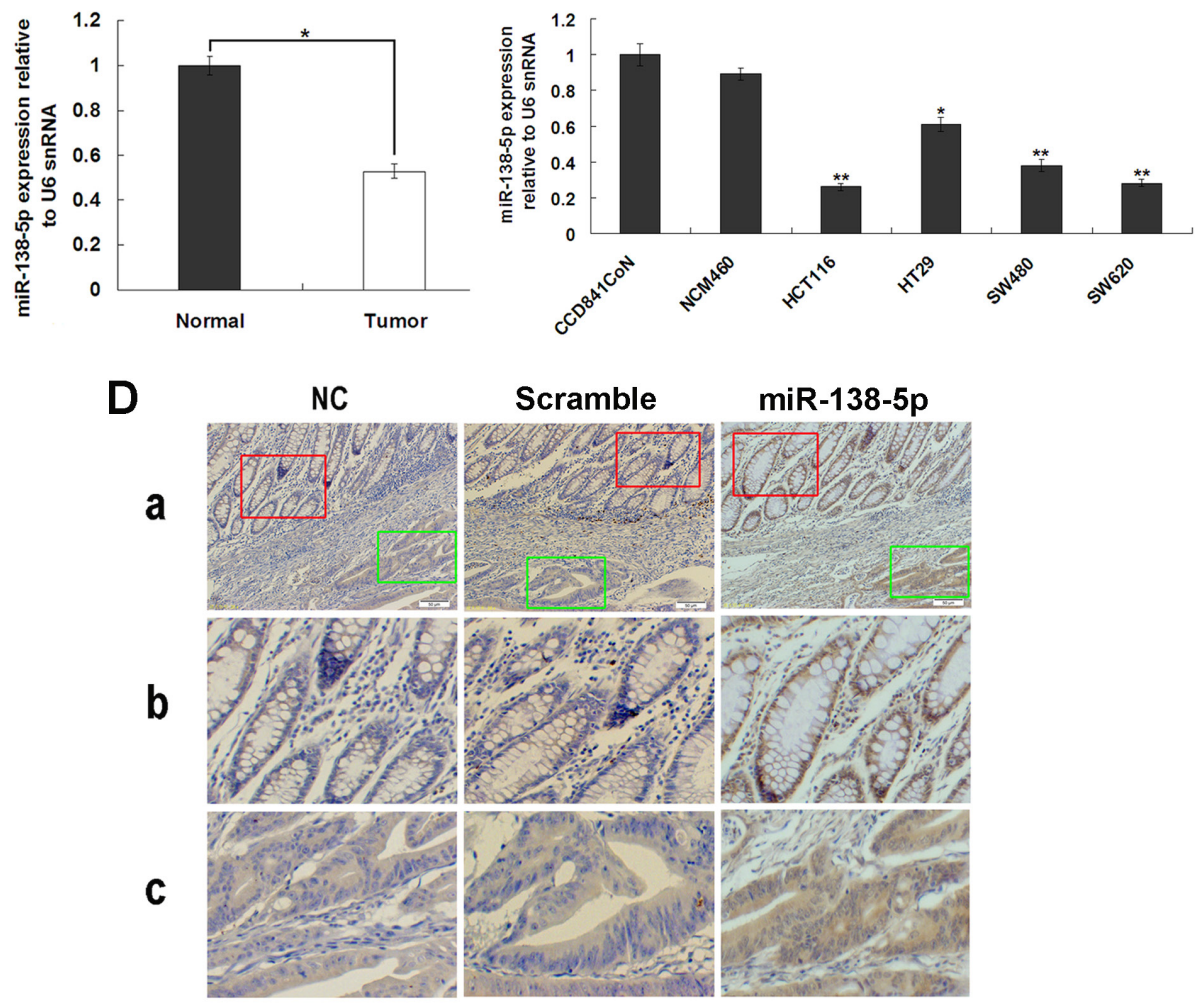

E

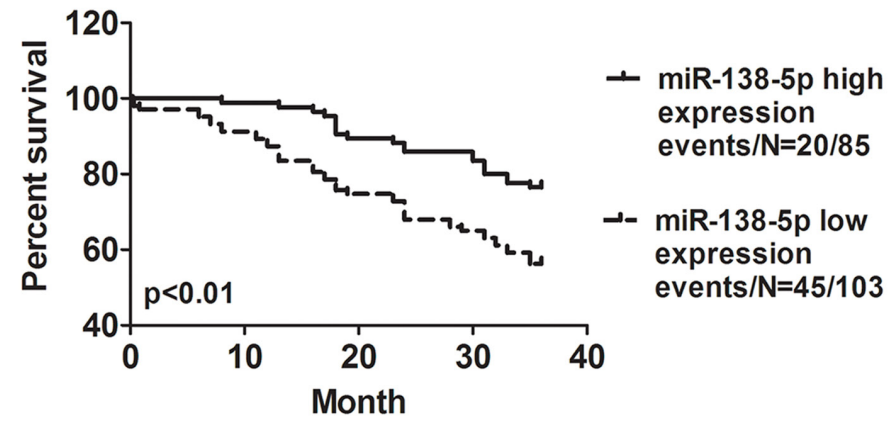

Figure 1: miR-138-5p is frequently downregulated in CRC. miR-138-5p expression in 21 CRC tissues and corresponding adjacent normal tissues as determined by qRT-PCR analysis A. U6 was the endogenous control. Relative miR-138-5p expression in CRC tissues B. miR-138-5p expression in two normal epithelial cell lines and four colon cancer cell lines as determined by qPCR $(* * P<0.01)$ C. U6 was the endogenous control. Data are presented as the mean \pm SD from at least three separate experiments. Detection of miR-138$5 p$ by ISH in CRC and corresponding adjacent normal tissues D. Tissue samples were cut into serial paraffin sections. "Scramble" and "NC, without probe" were used as controls. Row b shows magnified images of staining in adjacent normal tissues (red box in row a). Row c shows magnified images of staining in tumor tissues (green box in row a). Magnifications: $\times 100$ (a) and $\times 200$ (b and c). Kaplan-Meier analysis indicated that miR-138-5p downregulation was associated with poorer overall CRC patient survival $(P=0.001) \mathbf{E}$. 
Table 1: Correlations between clinicopathological features and miR-138-5p expression in CRC

\begin{tabular}{|c|c|c|c|c|}
\hline \multirow[t]{2}{*}{ Feature } & \multirow[t]{2}{*}{ All } & \multicolumn{3}{|c|}{ miR-138-5p level } \\
\hline & & Low (n) & High (n) & $P$-value \\
\hline \multicolumn{5}{|c|}{ PD-L1 expression } \\
\hline PD-L1 high & 98 & $73(74.5 \%)$ & $25(25.5 \%)$ & \\
\hline PD-L1 low & 90 & $30(33.3 \%)$ & $60(66.7 \%)$ & $0.000^{*}$ \\
\hline \multicolumn{5}{|l|}{ age } \\
\hline$<55$ & 87 & $47(54.0 \%)$ & $40(46.0 \%)$ & 0.884 \\
\hline$\geq 55$ & 101 & $56(55.4 \%)$ & $45(44.6 \%)$ & \\
\hline \multicolumn{5}{|l|}{ sex } \\
\hline Male & 120 & $67(55.8 \%)$ & $53(44.2 \%)$ & 0.702 \\
\hline Female & 68 & $36(52.9 \%)$ & $32(47.1 \%)$ & \\
\hline \multicolumn{5}{|c|}{ Differentiation } \\
\hline Well & 61 & $34(55.7 \%)$ & $27(44.3 \%)$ & 0.855 \\
\hline Moderate & 98 & $52(53.1 \%)$ & $46(46.9 \%)$ & \\
\hline Poor & 29 & $17(58.6 \%)$ & $12(41.4 \%)$ & \\
\hline \multicolumn{5}{|l|}{ T status } \\
\hline $\mathrm{T} 1$ & 9 & $9(8.7 \%)$ & $0(0.0 \%)$ & $0.008^{*}$ \\
\hline $\mathrm{T} 2$ & 14 & $11(10.7 \%)$ & $3(3.5 \%)$ & \\
\hline $\mathrm{T} 3$ & 153 & $77(74.8 \%)$ & $76(89.4 \%)$ & \\
\hline $\mathrm{T} 4$ & 12 & $6(5.8 \%)$ & $6(7.1 \%)$ & \\
\hline \multicolumn{5}{|l|}{ TNM stage } \\
\hline I & 20 & $18(90 \%)$ & $2(10 \%)$ & $0.000^{*}$ \\
\hline II & 78 & $31(39.7 \%)$ & $47(60.3 \%)$ & \\
\hline III & 60 & $33(55 \%)$ & $27(45 \%)$ & \\
\hline IV & 30 & $21(70 \%)$ & $9(30 \%)$ & \\
\hline \multicolumn{5}{|l|}{ Dukes stage } \\
\hline A stage & 30 & $21(70 \%)$ & $9(30 \%)$ & $0.022 *$ \\
\hline B stage & 66 & $27(40.9 \%)$ & $39(59.1 \%)$ & \\
\hline C stage & 57 & $32(56.1 \%)$ & $25(43.9 \%)$ & \\
\hline D stage & 35 & $23(65.7 \%)$ & $12(34.3 \%)$ & \\
\hline \multicolumn{5}{|l|}{$\begin{array}{l}\text { Lymph node } \\
\text { metastasis }\end{array}$} \\
\hline N0 & 98 & $39(37.9 \%)$ & $59(69.4 \%)$ & $0.000^{*}$ \\
\hline N1 & 90 & $64(62.1 \%)$ & $26(30.6 \%)$ & \\
\hline \multicolumn{5}{|l|}{ M status } \\
\hline M0 & 158 & $82(79.6 \%)$ & $76(89.4 \%)$ & 0.068 \\
\hline M1 & 30 & $21(20.4 \%)$ & $9(10.6 \%)$ & \\
\hline
\end{tabular}

$* P<0.05$. 
Table 2: Cox regression analysis of prognostic factors for overall CRC patient survival $(\mathrm{n}=188)$

\begin{tabular}{|c|c|c|c|c|}
\hline \multirow{2}{*}{$\begin{array}{l}\text { Clinicopathological } \\
\text { features }\end{array}$} & \multicolumn{2}{|c|}{ Univariate Analysis } & \multicolumn{2}{|c|}{ Multivariate Analysis } \\
\hline & HR $(95 \% \mathrm{Cl})$ & $P$-value & HR $(95 \% \mathrm{Cl})$ & $P$-value \\
\hline $\begin{array}{l}\text { miR-138-5p } \\
\text { downregulation }\end{array}$ & $0.466(0.274-0.790)$ & $0.001 *$ & $0.493(0.273-0.890)$ & $0.019 *$ \\
\hline Gender & $0.688(0.402-1.176)$ & 0.535 & & \\
\hline Age & $0.677(0.465-1.241)$ & 0.688 & & \\
\hline T status & $1.605(0.969-2.658)$ & 0.066 & $1.561(0.951-2.564)$ & 0.078 \\
\hline $\begin{array}{l}\text { Lymph node } \\
\text { metastasis }\end{array}$ & $1.990(1.393-2.841)$ & $<0.001 *$ & $1.831(1.296-2.587)$ & $0.001 *$ \\
\hline M status & $2.819(1.632-4.869)$ & $<0.001^{*}$ & $2.65(2.015-4.542)$ & $<0.001 *$ \\
\hline TNM stage & $2.623(1.959-3.512)$ & $<0.001 *$ & $2.004(1.384-2.901)$ & $<0.001 *$ \\
\hline Dukes stage & $2.793(2.093-3.728)$ & $<0.001^{*}$ & $2.113(1.492-2.992)$ & $<0.001 *$ \\
\hline
\end{tabular}

analyses (Figure 5D) revealed that PD-L1 expression was lower in tumors derived from SW620-miR-138-5p mice as compared to controls. These studies demonstrated that miR-138-5p downregulated PD-L1 and inhibited CRC cell tumorigenicity in nude mice.

\section{miR-138-5p and PD-L1 levels are negatively correlated in CRC}

We assessed PD-L1 and miR-138-5p levels in CRC tissues using ISH, IHC and qRT-PCR. We observed an inverse correlation between PD-L1 and miR-138-5p levels in tumor tissues by all methods (Figure 6A-6C). Patients with high PD-L1 expression had an increased risk of death ( $P=0.0024$, Figure 6D), indicating that PD-L1 expression could be a prognostic factor for CRC.

\section{DISCUSSION}

miRNAs, such as oncomiRs or anti-oncomiRs, play critical roles in the initiation and progression of human cancers through post-transcriptional regulation of gene expression [36]. Previous studies indicated that miR-138 might be a tumor suppressor in some cancers, including colorectal cancer, ovarian cancer, head and neck squamous cell carcinoma, nasopharyngeal carcinoma and pancreatic cancer [8, 24, 37-41]. However, the functional role and mechanistic action of miR-138-5p in CRC remained largely unclear. Our study showed miR-138-5p was downregulated in CRC tumor samples as compared with corresponding adjacent normal tissues (Figure 1). We examined the effects of miR-138-5p on CRC cells in vitro and in vivo. Our results indicated that miR-138$5 p$ reduced CRC cell proliferation and blocked the G1/S transition (Figure 3). In addition, we demonstrated that
miR-138-5p overexpression suppressed tumor growth in vivo (Figure 5).

PD-L1 expression has been studied in different cancers including melanoma and cancers of the kidney, lung, pancreas, esophagus, ovary, colorectal, breast, head and neck, and was correlated with clinicopathological tumor features in several studies [42-49]. Recent clinical trials demonstrated that blocking the PD-1/PD-L1 pathway induces durable remission in patients with advanced solid tumors. Colorectal cancer appeared to respond poorly to PD-1 or PD-L1 antibody blockade in a clinical trial [50]. Several other factors may be involved in CRC patient survival time [51, 52], and the role of PD-L1 in CRC cells must be further investigated.

miRNAs are known to perform their biological functions by downregulating expression of their target genes. The predicted miR-138-5p binding site was present in PD-L1 3' UTRs. Whether PD-L1 is the only direct target of miR-138-5p is still unknown. Luciferase activity assay results verified that PD-L1 was a target of miR-138-5p. PD-L1 levels were decreased by ectopic miR-138-5p expression in CRC cells (Figure 2Da). The present study showed that PD-L1 overexpression in CRC cells can rescue them from miR-138-5p-induced cell cycle arrest and reduced proliferation (Figure 3). The tumor suppressive role of miR-138-5p in CRC is thus at least partly realized by downregulating PD-L1. A previous study demonstrated that PD-L1 knockdown by siRNA reduced cell proliferation in vitro similarly to miR-138 restoration [33]. We demonstrated a direct link between miR-138-5p and PD-L1 expression in CRC patients, and observed that PD-L1 and miR-138-5p levels were inversely correlated in human CRC specimens (Figure 6C). We also showed that low miR-138-5p expression correlated with advanced clinical stage and lymph node 
A

a

\begin{tabular}{l|l}
$\begin{array}{l}\text { Position 3595-3619 of } \\
\text { PD-L1 3'UTR }\end{array}$ & 5'-TATTTTGTT ACTTGGTACACCAGCA-3' \\
hsa-miR-138-5p & 3'-GCCGGACUAAGUGUUGUGGUCGA-5' \\
mut 3'UTR & 5'-TATTTTGTT ACTTGGTA- | | |
\end{tabular}

b

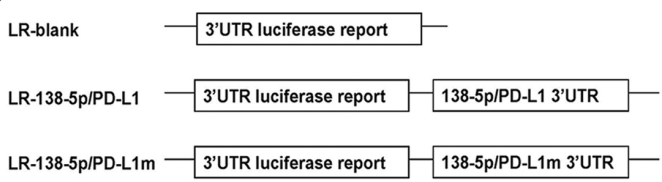

B

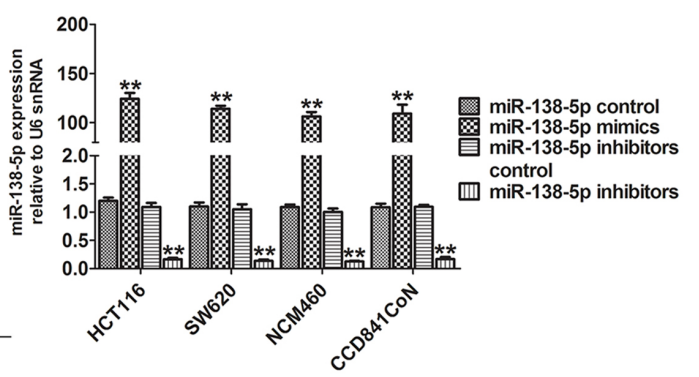

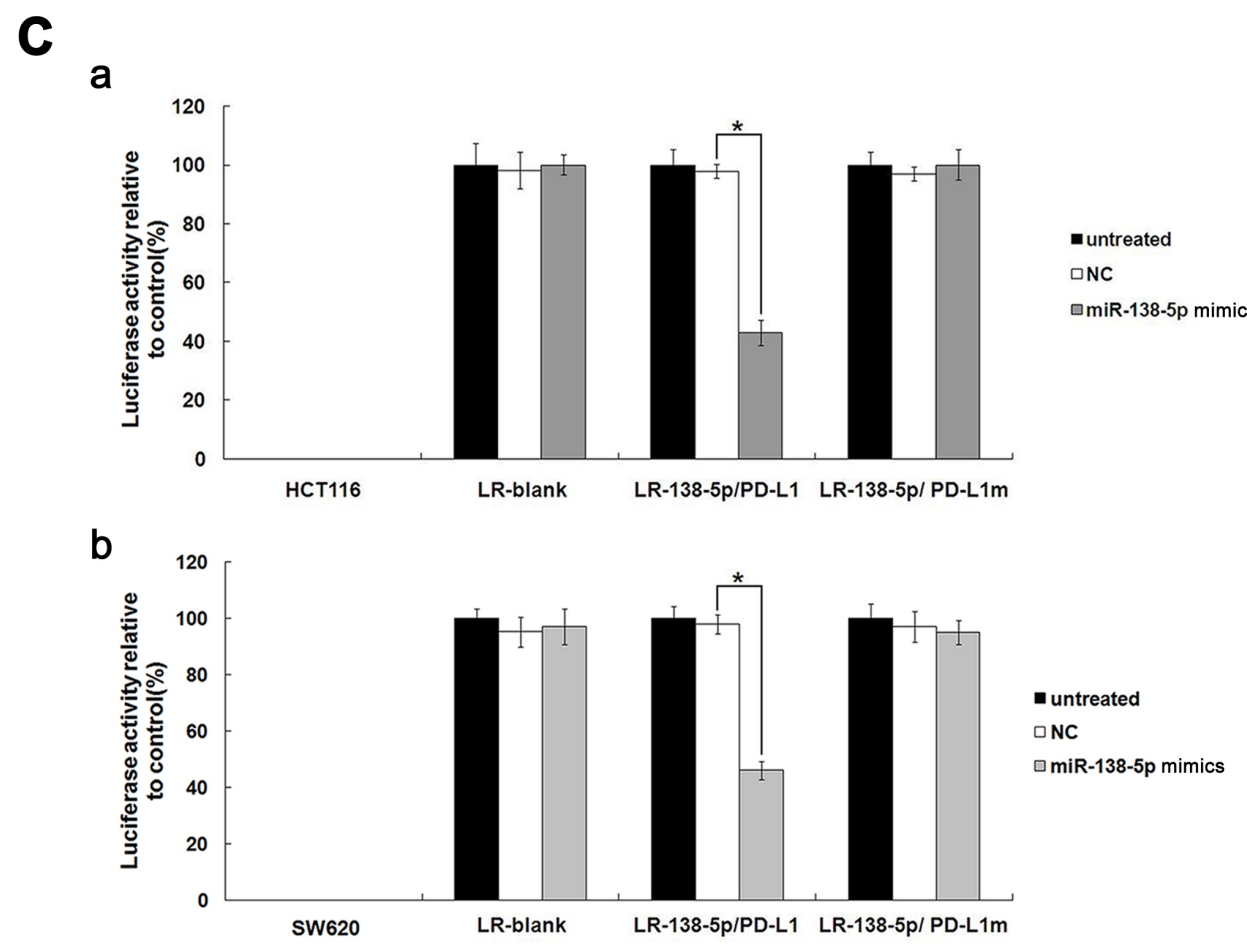

D
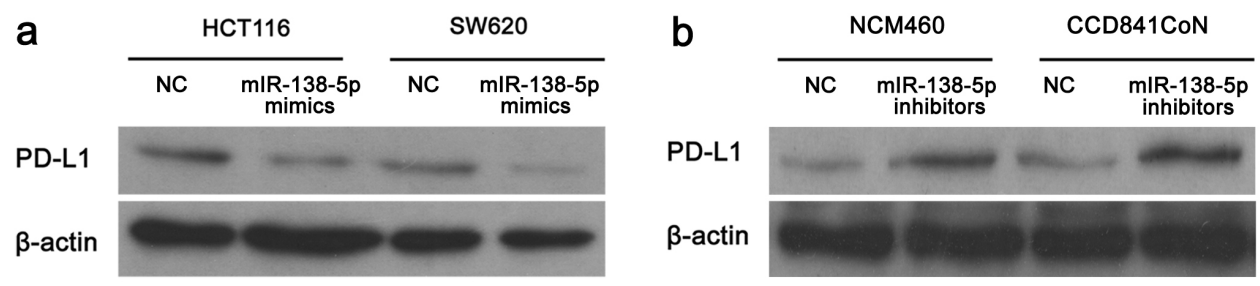

Figure 2: PD-L1 is a direct target of miR-138-5p in CRC cells. Base pairing between miR-138-5p and PD-L1 was predicted by MIRBASE software. Schematic representation of the three reporter constructs: LR-blank, LR-138-5p/PD-L1 and LR-138-5p/PD-L1m (where "m" indicates the mutant construct) Aa. LR, luciferase reporter Ab. miR-138-5p expression was detected via qPCR in HCT116, SW620, NCM460 and CCD841CoN cells transfected with miR-138-5p mimics and inhibitors $(* * P<0.01)$. B. Data were confirmed in three experiments. Each of the luciferase reporter plasmids was cotransfected as indicated (untreated; NC, scramble; miR-138-5p mimic) into HCT116 Ca. and SW620 Cb. cells. Luciferase activity was measured after $36 \mathrm{~h}$, and transfection efficiency differences were normalized to renal activity $(* P<0.05)$. Data were confirmed in three experiments. PD-L1 was detected via western blotting in HCT116 and SW620 cells transfected for $48 \mathrm{~h}$ with miR-138-5p mimics or NC oligos (miR-138-5p mimics control) Da. PD-L1 was detected in NCM460 and CCD841CoN cells transfected for $48 \mathrm{~h}$ with miR-138-5p inhibitors or NC oligos (miR-138-5p inhibitors control) Db. 
A

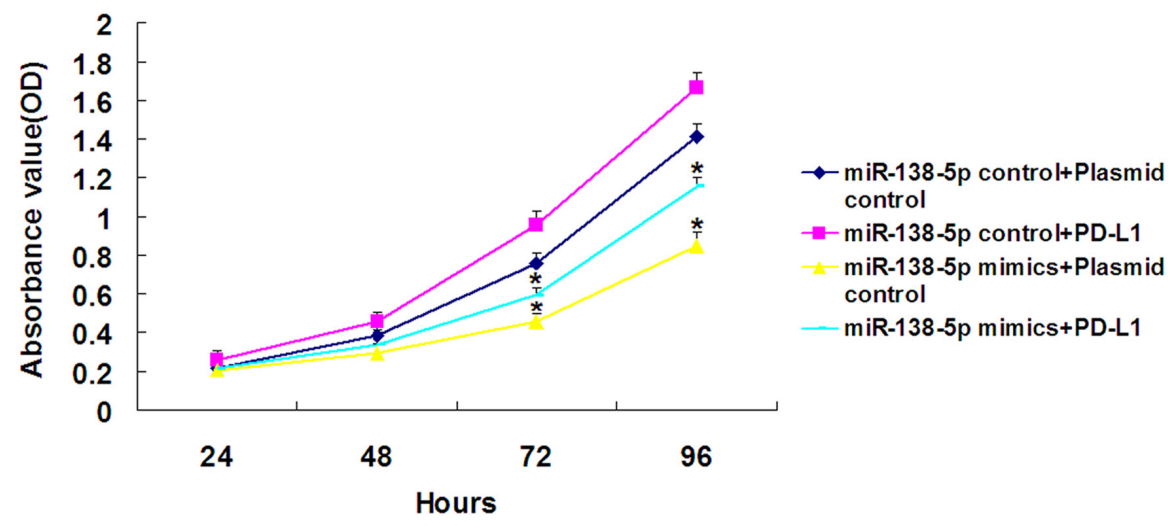

B

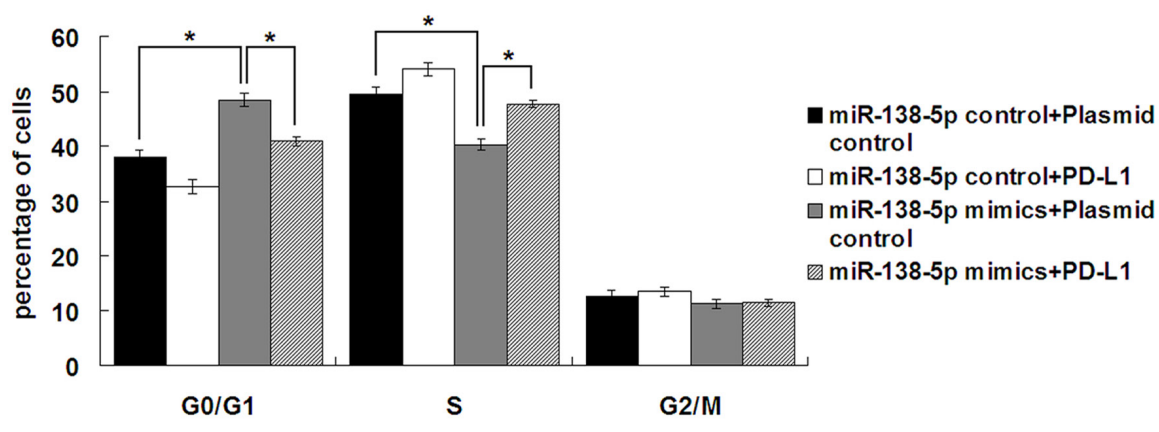

C

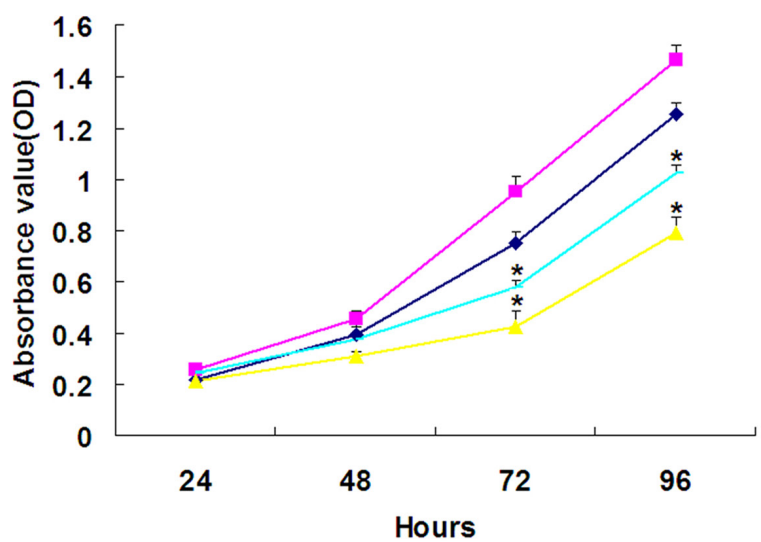

$\leftarrow$ miR-138-5p control+Plasmid control

- miR-138-5p control+PD-L1

miR-138-5p mimics+Plasmid control

- miR-138-5p mimics+PD-L1

D

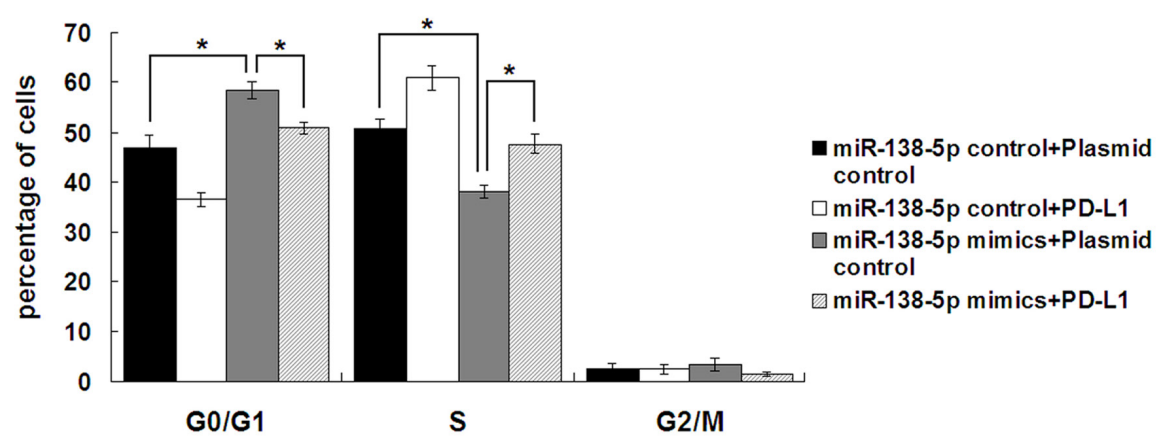

Figure 3: PD-L1 overexpression reversed the effects of miR-138-5p on cell cycle distribution and proliferation in CRC cell lines. HCT116 cell proliferation A. and cell cycle distribution B. after cotransfection with miR-138-5p and PD-L1 or control plasmids. SW620 cell proliferation C. and cell cycle distribution D. after cotransfection with miR-138-5p and PD-L1 or control plasmids. Data were confirmed in three experiments $(* P<0.05)$. 
A

NC PD-L1 siRNA untreated

B
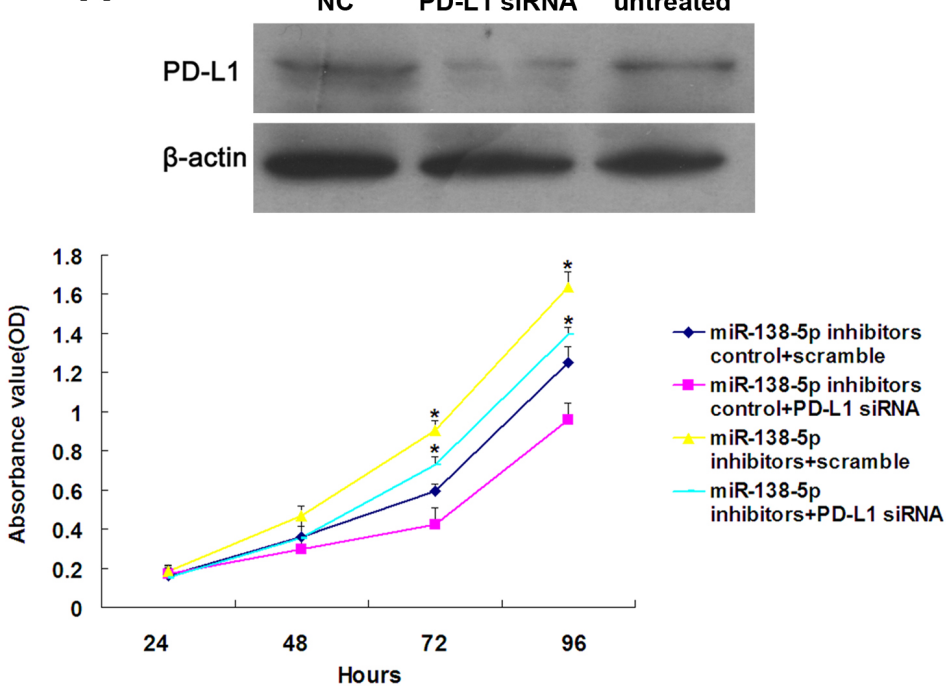

C

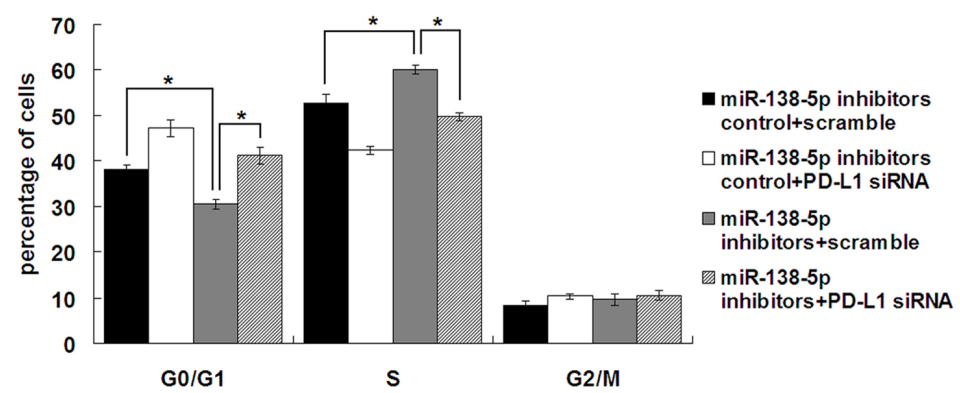

D

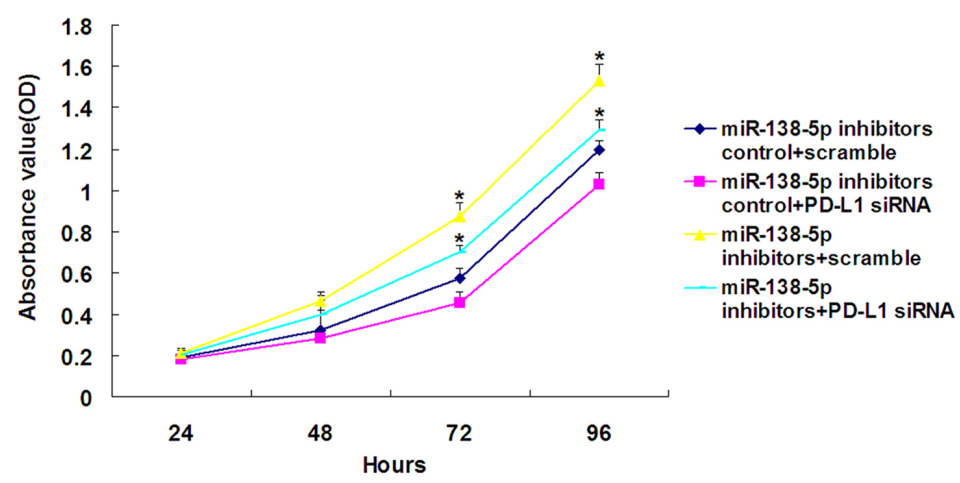

$\mathbf{E}$

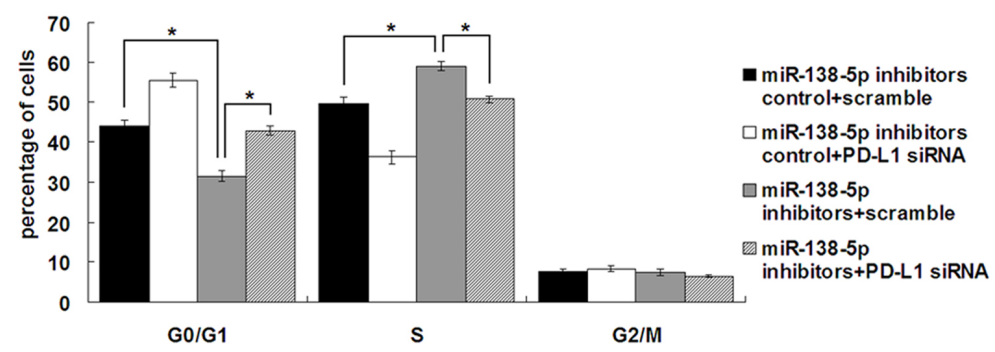

Figure 4: The growth-promoting effects of miR-138-5p inhibition were attenuated by endogenous PD-L1 knockdown in colonic epithelium cells. Western blot analysis of PD-L1 in NCM460 cells $48 \mathrm{~h}$ post-transfection with PD-L1 siRNA A. "NC, scramble" and untreated were used as controls. NCM460 cell proliferation B. and cell cycle progression $\mathbf{C}$. after cotransfection with the miR-138-5p inhibitor and PD-L1 siRNA or scramble. CCD841CoN cell proliferation D. and cell cycle distribution E. after cotransfection with the miR-138-5p inhibitor and PD-L1 siRNA or scramble. Data were confirmed in three experiments $\left({ }^{*} P<0.05\right)$. 
A

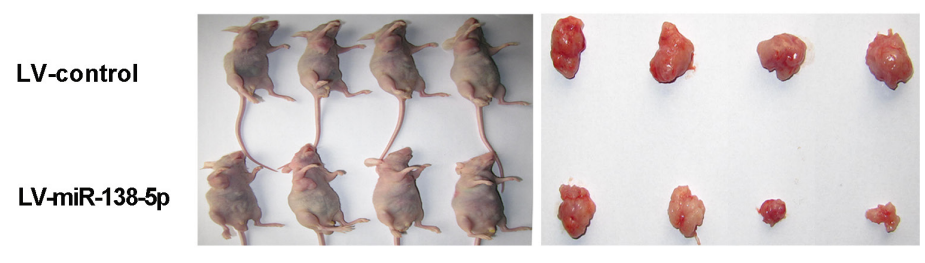

B

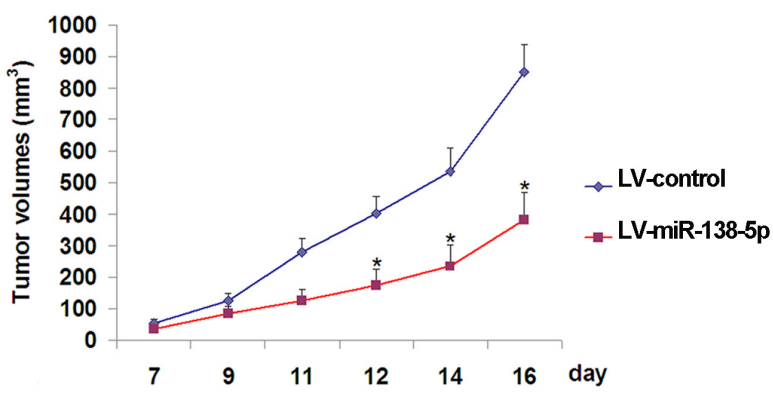

C

LV-control

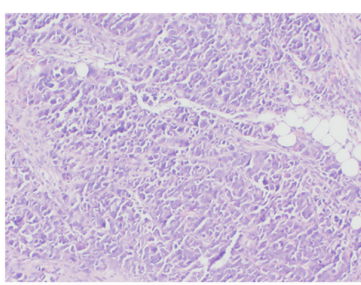

H\&E

NC
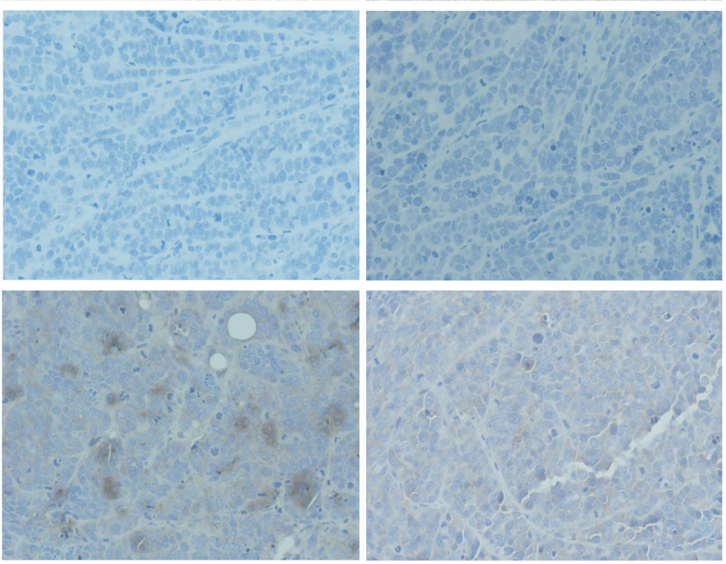

D

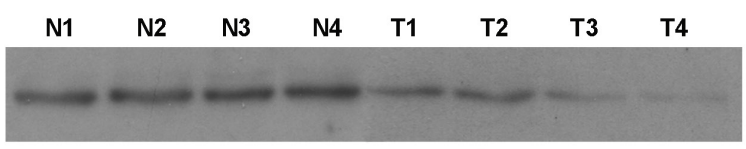

$\beta$-actin

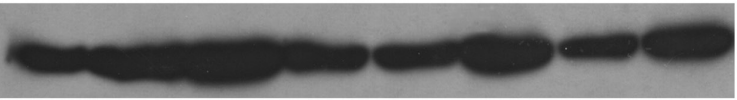

Figure 5: miR-138-5p suppressed SW620 cell tumor growth in vivo. SW620 cells were infected with LV-miR-138-5p or LVcontrol, and six million cells in $0.2 \mathrm{ml}$ of growth medium were subcutaneously injected into BALB/c nude mice (four in each group). Tumor formation in SW620-LV-miR-138-5p or SW620-LV-control nude mice A. Tumor volume was significantly lower in SW620-LVmiR-138-5p mice as compared with SW620-LV-control mice $(* P<0.05)$ B. Data is presented as the mean \pm standard deviation (SD) of four mice. PD-L1-stained SW260-LV-miR-138-5p and SW620-LV-control tumors $16 \mathrm{~d}$ after transplantation (magnification: $\times 200$ ) C. PD-L1 detected in tumors via western blotting $16 \mathrm{~d}$ after transplantation D. N1-N4 were derived from SW620-LV-control mice and T1-T4 were from SW620-LV-miR-138-5p mice. 
A

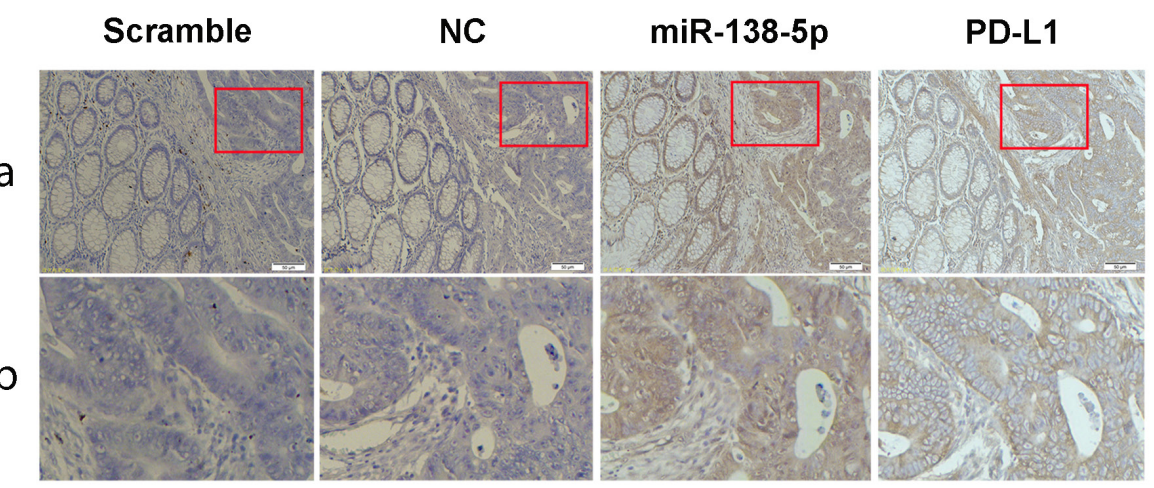

B
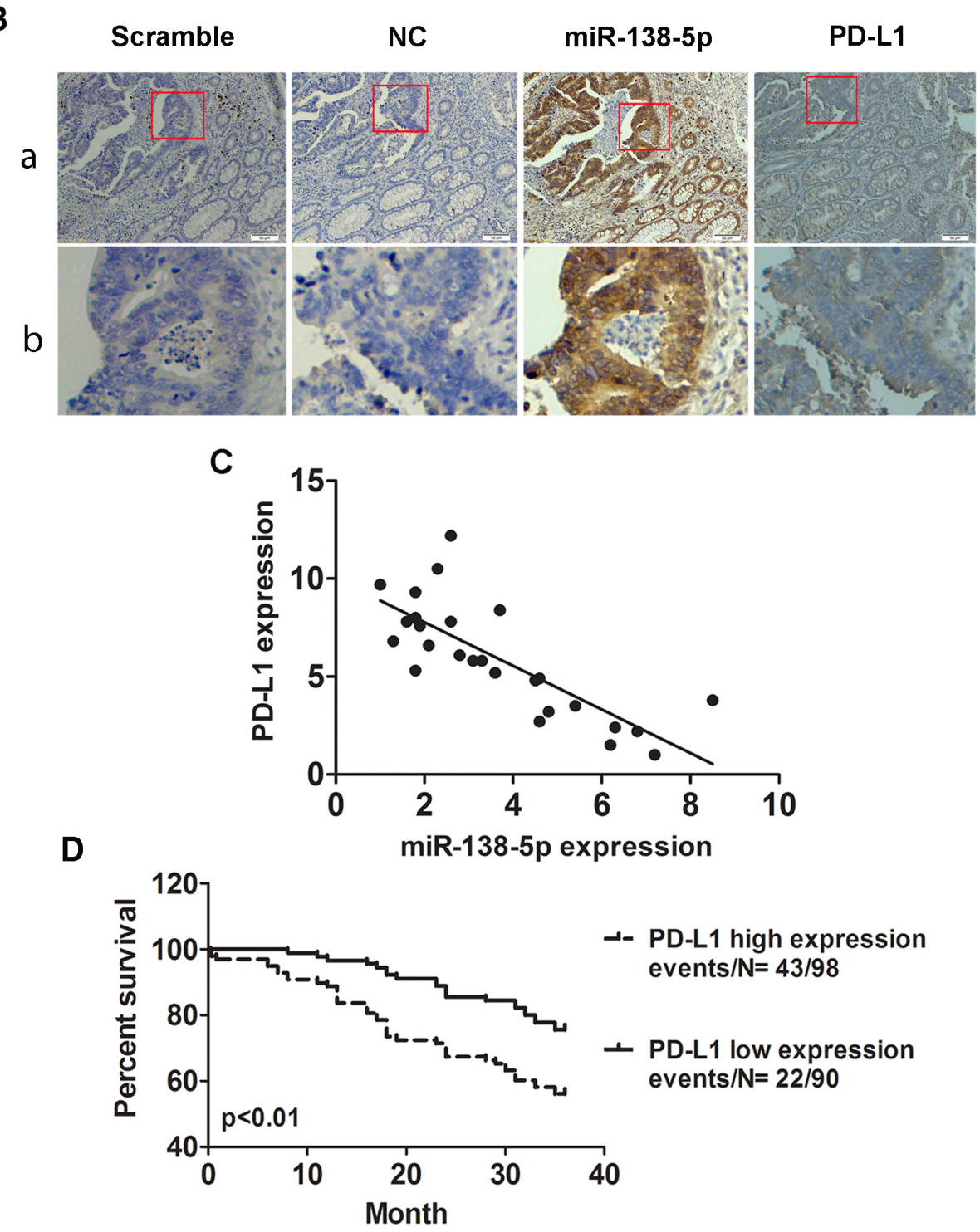

Figure 6: Correlation between miR-138-5p and PD-L1 expression in human CRCs. ISH detection of miR-138-5p and IHC detection of PD-L1 in CRCs with low A. or high B. miR-138-5p expression tissue samples which were cut into serial paraffin sections. "Scramble, miR-138-5p negative control sequence" was the ISH negative control and "NC" was the IHC negative control. Row b shows magnified tumor tissue images (red box in row a). Magnifications: $\times 100$ (a) and $\times 200$ (b). miR-138-5p and PD-L1 mRNA levels were inversely correlated in CRC tissue samples (two-tailed pearson's correlation analysis, $\mathrm{r}=-0.785 ; P<0.01$ ) C. Kaplan-Meier analysis indicated that PD-L1 upregulation was associated with poorer overall patient survival $(\mathrm{P}=0.0024) \mathbf{D}$. 
metastasis. Importantly, low miR-138-5p (Figure 1D) and high PD-L1 levels (Figure 5D) were correlated with shorter overall CRC patient survival, indicating that miR-138-5p and PD-L1 may serve as CRC biomarkers for risk group assignment, optimal therapy selection and clinical outcome prediction. Targeting PD-L1, possibly by administering miR-138-5p mimics, might be a clinically effective anti-CRC therapeutic strategy.

\section{MATERIALS AND METHODS}

\section{Cell lines, plasmids and miRNAs}

The human CRC cell lines HCT116, SW620, SW480 and HT29 and human normal colonic epithelium cell lines NCM460 and CCD841CoN were obtained from the Chinese Academy Medical Science (Beijing, China). CRC cell lines were cultured in RPMI-1640 medium containing 10\% fetal bovine serum (FBS). NCM460 and CCD841CoN cell lines were cultured in DMEM medium containing $15 \%$ FBS. Cells were cultured at $37^{\circ} \mathrm{C}$ with $5 \% \mathrm{CO}_{2}$. miRNA mimics, inhibitors and negative control sequences were synthesized and purified by Shanghai Gene Pharma Co (Shanghai, China). The PD-L1 expression plasmid was obtained from OriGene (Beijing, China).

\section{Tumor samples}

CRC patient tumor samples were collected from the Xiangya First, Second, and Third Hospitals of Central South University. Written informed consent was obtained from all study participants. Tissue sample collection and use protocols were approved by the ethical review committees of the Xiangya Hospital Ethic Committee of Central South University.

\section{Quantitative real-time PCR}

Total RNA was isolated from CRC surgical specimens and reverse transcribed as previously described [53]. Real-time quantitative PCR was performed using an IQ5 Multicolor Detection System (Bio-Rad) with a Hairpin-it miRNAs qPCR Quantification Kit (GenePharma, Shanghai, China) according to the manufacturer's instructions. The primers used for miRNA detection by qRT-PCR were designed based on sequences provided by the Sanger Center miRNA Registry. The U6 snRNA was used as an endogenous control. The following program was used for the RT reaction: $16^{\circ} \mathrm{C}$ for $30 \mathrm{~min}, 42^{\circ} \mathrm{C}$ for $30 \mathrm{~min}$ and $85^{\circ} \mathrm{C}$ for $10 \mathrm{~min}$. The following program was used for qPCR: $95^{\circ} \mathrm{C}$ for $3 \mathrm{~min}, 40$ cycles of $95^{\circ} \mathrm{C}$ for $12 \mathrm{~s}$ and then $62^{\circ} \mathrm{C}$ for $35 \mathrm{~s}$. The primers used were PD-L1 (forward, 5'-CATCTTATTATGCCTTGGTGTAGCA-3'; reverse, 5'- GGATTACGTCTCCTCCAAATGTG-3') and $\beta$-actin (forward, 5'-GCATCCCCCAAAGTTCACAA-3'; reverse,
5'-AGGACTGGGCCATTCTCCTT-3'). The following program was used for PCR: $94^{\circ} \mathrm{C}$ for $5 \mathrm{~min}, 35$ cycles of $94^{\circ} \mathrm{C}$ for $30 \mathrm{~s}, 58^{\circ} \mathrm{C}$ for $40 \mathrm{~s}$ and $72^{\circ} \mathrm{C}$ for $30 \mathrm{~s}$, and then $72^{\circ} \mathrm{C}$ for $10 \mathrm{~min}$. Relative expression changes were calculated using the $2^{-\Delta \Delta \mathrm{CT}}$ (where CT is threshold cycle) method. Three parallel repeats were performed for each sample in each experiment and results were expressed as the mean of three independent experiments.

\section{Cell proliferation assay}

CRC cells were transfected with miR-138-5p mimics or inhibitors for $24 \mathrm{~h}$, and proliferation was examined. Briefly, 2000 cells from each group (untreated, miR-138-5p mimics, miR-138p inhibitors and negative control) were plated in each well of five 96-well plates in $200 \mu \mathrm{L}$ of medium. Cells were treated with $20 \mu \mathrm{L}$ of $5 \mathrm{mg} /$ ml MTT (tetrazoliumsalt 3-[4,5-dimethylthiazole-2-yl]2,5-diphenyltetrazolium bromide) in complete medium for $4 \mathrm{~h}$, and were then dissolved in dimethylsulfoxide (DMSO). Absorbance at $490 \mathrm{~nm}$ was measured using an enzyme-linked immunosorbent assay (ELISA) plate reader (Sunrise remote, Tecan Austria $\mathrm{GmbH}$ ). One plate was analyzed immediately after cells adhered (approximately $4 \mathrm{~h}$ after plating). One plate per day was examined for the next four days. Each experiment was repeated three times independently.

\section{Flow cytometry analysis}

Cells were washed twice with phosphate-buffered saline (PBS) and fixed in 70\% ethanol overnight. Then, cells were centrifuged at $1,200 \times \mathrm{g}$ for $5 \mathrm{~min}$, resuspended in $50 \mu \mathrm{g} / \mathrm{ml}$ propidium iodide (Sigma-Aldrich) in PBS and immediately analyzed by flow cytometry using a MOFLO XDP flow cytometer (Beckman Coulter, Fullerton, CA). The appropriate forward and side scatter gates were used, and $1 \times 10^{5}$ cells were examined per experiment. Data were analyzed with Modfit software (Verity Software House, Topsham, ME) and values were expressed as the mean and standard deviation of three independent experiments.

\section{siRNAs and western blotting}

The PD-L1-specific siRNA sequence (GenBank Accession No.NM_014143) [54] was 5'-GATATTTGCTGTCTTTATA-3'. PD-L1 siRNA and scramble sequences were synthesized and purified by Shanghai Gene-Pharma Co. (Shanghai, China) and transfected into cells using Lipofectamine 2000 reagent (Invitrogen, USA) according to the manufacturer's instructions.

Western blotting was performed as described previously [53]. The $\beta$-actin antibody was purchased from Sigma-Aldrich (St.Louis, MO) and the PD-L1 antibody was obtained from Millipore (Cat.ABC324). 


\section{In situ hybridization and immunohistochemistry}

ISH was used to detect miR-138-5p expression in CRC tissue samples. Oligonucleotide probes complementary to hsa-miR-138-5p (where hsa indicates Homo sapiens) (product 38511-01; Exiqon) and scramble (normal control) were digoxigenin labeled at the $5^{\prime}$ terminal end. Tumor and corresponding adjacent normal tissues were formalin fixed, paraffin embedded and sectioned. Probes were detected using an enhanced sensitive ISH detection kit (Boster Inc., Wuhan, China) according to the manufacturer's instructions. Negative controls did not include probes. MiR-138-5p staining was scored according to intensity and proportion: $0-1(0-$ $25 \%), 1-2(26-50 \%), 2-3(51-75 \%)$, and 3-4 (76-100\%).

The sum of intensity and percentage counts was used as the final score. Expression scores greater than or equal to 2 were defined as high, whereas scores lower than 2 were indicative of low expression. The detailed method was applied as previously described [55].

To examine PD-L1 expression in tissues via IHC, sectioned specimens were deparaffinized and dehydrated. Samples that were not exposed to the primary antibody were used as negative controls. The scoring system used in grading PD-L1 expression was described previously [56]. Tumors with strong or moderate immunostaining intensity were classified as having positive $(+)$ expression, whereas tumors with absent or weak immunostaining were classified as having negative (-) expression. miR-138-5p and PD-L1 staining were scored independently by two pathologists blinded to patient clinical characteristics.

\section{Luciferase reporter assay}

Basic information about hsa-miR-138-5p was collected from miRBase (http://microrna.sanger.ac.uk/ sequences). The sequence and the possible targets were predicted by the online software MIRDB (http://mirdb. org/cgi-bin/search.cgi? searchType=miRNA\& full $=$ mirba se\&searchBox=MIMAT0000430). Two single strands of the target gene $3^{\prime}$ UTR containing the miRNA binding sites were synthesized (accession number NM_014143 for PD-L1). Two single strands of the target gene 3' UTR with 7 bases deleted in the miR-138-5p binding site were synthesized as mutant controls. HindIII and SpeI restriction sites were inserted at both ends of the oligonucleotides for further cloning. The following oligonucleotides were used in this study: the $3^{\prime}$ UTR of PD-L1 (sense, 5'- CTA GTAAATATTCTTATTTATTTTGTTACTTGGTACACC AGCATGTCCATTTTCTTGTTTATTTTA-3'; antisense, 5'- AGCTTAAAATAAACAAGAAAATGGACATGCT GGTGTACCAAGTAACAAAATAAATAAGAATATT

TA-3') and the 3' UTR of mutant PD-L1 (sense, 5'- CT AGTAAATATTCTTATTTATTTTGTTACTTGGTA------ATGTCCATTTTCTTGTTTATTTTA-3'; antisense, 5'-AGCTTAAAATAAACAAGAAAATGGACAT------TACCAAGTAACAAAATAAATAAGAATATT
TA-3'; dashes indicate CACCAGC deletion). Sense and antisense strands were annealed, digested with HindIII and SpeI, and ligated into the pmir-Report luciferase vector (Ambion, Austin, TX). Three luciferase reporters (LRs) were constructed: LR-blank (no insertion), LR-138-5p/ PD-L1 and LR-138-5p/PD-L1m (where $\mathrm{m}$ indicates mutant). Cells were seeded into 24-well plates and 300ng of reporter plasmid, $30 \mathrm{ng}$ of renal plasmid and $20 \mathrm{nmol}$ of miR-138-5p mimic were cotransfected into cells using Attractene Transfection Reagent. Cell lysates were collected $36 \mathrm{~h}$ post-transfection and assayed for luciferase activity using a luciferase assay kit (Promega, Madison, WI). Renal activity was measured using an enzyme assay kit (Promega) and results were normalized to renal activity.

\section{Experiments in nude mice}

Four-week-old specific-pathogen-free (SPF) $\mathrm{BALB} / \mathrm{c}$ nude mice were purchased from SLAC Laboratory Animal Co., Ltd. (Shanghai, China). All animal procedures were performed according to approved protocols and in accordance with recommendations for the proper use and care of laboratory animals. A xenograft model was used to examine the effects of miR$138-5 \mathrm{p}$ on tumor growth in CRC cells in vivo. SW-620 cells were infected with LV-miR138-5p or LV-scramble, and six million cells in $0.2 \mathrm{ml}$ of growth medium were subcutaneously injected into BALB/c nude mice. The first tumor was detected one week after inoculation. Mice were killed $9 \mathrm{~d}$ after the initial tumor detection, and tumors were harvested, weighed and snap frozen.

\section{Statistical analysis}

The differences between groups were tested examined using the Student's t test or a one-way analysis of variance (ANOVA) test. Survival analysis was performed using Kaplan-Meier plots and log-rank tests. Correlations between miR-138-5p expression and clinicopathological characteristics were analyzed by Pearson's $\chi^{2}$ test and Fisher's exact test. Univariate and multivariate Cox proportional hazard regression models were used to assess survival hazard. Statistical analyses were performed using SPSS v16.0. Differences were considered significant when $P<0.05$.

\section{CONFLICTS OF INTEREST}

The authors declare no conflicts of interest.

\section{GRANT SUPPORT}

This work was supported by the National Natural Science Youth Foundation of China (81402272), the Hunan Provincial Natural Science Foundation of China 
(11JJ4071) and the Freedom Explore Program of Central South University (2011QNZT192).

\section{REFERENCES}

1. Siegel R, Naishadham D, Jemal A. Cancer statistics, 2012. CA: a cancer journal for clinicians. 2012; 62:10-29.

2. Gellad ZF, Provenzale D. Colorectal cancer: national and international perspective on the burden of disease and public health impact. Gastroenterology. 2010; 138:2177-90.

3. Bartel DP. MicroRNAs: genomics, biogenesis, mechanism, and function. Cell. 2004; 116:281-97.

4. Yu X, Li Z. The role of microRNAs expression in laryngeal cancer. Oncotarget. 2015; 6:23297-305. doi: 10.18632/ oncotarget.4195.

5. Lee SH, Jung YD, Choi YS, Lee YM. Targeting of RUNX3 by miR-130a and miR-495 cooperatively increases cell proliferation and tumor angiogenesis in gastric cancer cells. Oncotarget. 2015; 6:33269-78. doi: 10.18632/ oncotarget.5037.

6. Kim HS, Lee KS, Bae HJ, Eun JW, Shen Q, Park SJ, Shin WC, Yang HD, Park M, Park WS, Kang YK, Nam SW. MicroRNA-31 functions as a tumor suppressor by regulating cell cycle and epithelial-mesenchymal transition regulatory proteins in liver cancer. Oncotarget. 2015; 6:8089-102. doi: 10.18632/oncotarget.3512.

7. Liu Y, Wang Y, Sun X, Mei C, Wang L, Li Z, Zha X. miR-449a promotes liver cancer cell apoptosis by downregulation of Calpain6 and POU2F1. Oncotarget. 2015; 7:13491-501. doi: 10.18632/oncotarget.4821.

8. Zheng H, Ma R, Wang Q, Zhang P, Li D, Wang Q, Wang J, Li H, Liu H, Wang Z. MiR-625-3p promotes cell migration and invasion via inhibition of SCAI in colorectal carcinoma cells. Oncotarget. 2015; 6:27805-15. doi: 10.18632/ oncotarget. 4738 .

9. Li W, Chang J, Wang S, Liu X, Peng J, Huang D, Sun M, Chen Z, Zhang W, Guo W, Li J. miRNA-99b-5p suppresses liver metastasis of colorectal cancer by down-regulating mTOR. Oncotarget. 2015; 6:24448-62. doi: 10.18632/ oncotarget.4423.

10. Ma F, Song H, Guo B, Zhang Y, Zheng Y, Lin C, Wu Y, Guan G, Sha R, Zhou Q, Wang D, Zhou X, Li J, et al. MiR361-5p inhibits colorectal and gastric cancer growth and metastasis by targeting staphylococcal nuclease domain containing-1. Oncotarget. 2015; 6:17404-16. doi: 10.18632/ oncotarget.3744.

11. Fang L, Li H, Wang L, Hu J, Jin T, Wang J, Yang BB. MicroRNA-17-5p promotes chemotherapeutic drug resistance and tumour metastasis of colorectal cancer by repressing PTEN expression. Oncotarget. 2014; 5:297487. doi: 10.18632/oncotarget.1614.

12. Smith AR, Marquez RT, Tsao WC, Pathak S, Roy A, Ping J, Wilkerson B, Lan L, Meng W, Neufeld KL, Sun XF, Xu L. Tumor suppressive microRNA-137 negatively regulates
Musashi-1 and colorectal cancer progression. Oncotarget. 2015; 6:12558-73. doi: 10.18632/oncotarget.3726.

13. Huang Z, Huang S, Wang Q, Liang L, Ni S, Wang L, Sheng W, He X, Du X. MicroRNA-95 promotes cell proliferation and targets sorting Nexin 1 in human colorectal carcinoma. Cancer research. 2011; 71:2582-89.

14. Jahid S, Sun J, Edwards RA, Dizon D, Panarelli NC, Milsom JW, Sikandar SS, Gumus ZH, Lipkin SM. miR-23a promotes the transition from indolent to invasive colorectal cancer. Cancer discovery. 2012; 2:540-53.

15. Wang Z, Wei W, Sarkar FH. miR-23a, a critical regulator of "migR"ation and metastasis in colorectal cancer. Cancer discovery. 2012; 2:489-91.

16. Ma F, Song H, Guo B, Zhang Y, Zheng Y, Lin C, Wu Y, Guan G, Sha R, Zhou Q, Wang D, Zhou X, Li J, et al. MiR361-5p inhibits colorectal and gastric cancer growth and metastasis by targeting staphylococcal nuclease domain containing-1. Oncotarget. 2015; 6:17404-16. doi: 10.18632/ oncotarget.3744.

17. Ma Y, Zhang P, Wang F, Zhang H, Yang J, Peng J, Liu W, Qin H. miR-150 as a potential biomarker associated with prognosis and therapeutic outcome in colorectal cancer. Gut. 2012; 61:1447-53.

18. Zhang XF, Li KK, Gao L, Li SZ, Chen K, Zhang JB, Wang D, Tu RF, Zhang JX, Tao KX, Wang G, Zhang XD. miR-191 promotes tumorigenesis of human colorectal cancer through targeting C/EBPbeta. Oncotarget. 2015; 6:4144-58. doi: 10.18632/oncotarget.2864.

19. Zhang C, Liu J, Wang X, Wu R, Lin M, Laddha SV, Yang Q, Chan CS, Feng Z. MicroRNA-339-5p inhibits colorectal tumorigenesis through regulation of the MDM2/ p53 signaling. Oncotarget. 2014; 5:9106-17. doi: 10.18632/ oncotarget.2379.

20. Sun Y, Shen S, Liu X, Tang H, Wang Z, Yu Z, Li X, Wu M. MiR-429 inhibits cells growth and invasion and regulates EMT-related marker genes by targeting Onecut 2 in colorectal carcinoma. Molecular and cellular biochemistry. 2014; 390:19-30.

21. Tang JT, Wang JL, Du W, Hong J, Zhao SL, Wang YC, Xiong H, Chen HM, Fang JY. MicroRNA 345, a methylation-sensitive microRNA is involved in cell proliferation and invasion in human colorectal cancer. Carcinogenesis. 2011; 32:1207-15.

22. Zhang H, Tang J, Li C, Kong J, Wang J, Wu Y, Xu E, Lai M. MiR-22 regulates 5-FU sensitivity by inhibiting autophagy and promoting apoptosis in colorectal cancer cells. Cancer letters. 2015; 356:781-90.

23. Zhang J, Fei B, Wang Q, Song M, Yin Y, Zhang B, Ni S, Guo W, Bian Z, Quan C, Liu Z, Wang Y, Yu J, et al. MicroRNA-638 inhibits cell proliferation, invasion and regulates cell cycle by targeting tetraspanin 1 in human colorectal carcinoma. Oncotarget. 2014; 5:12083-96. doi: 10.18632/oncotarget.2499. 
24. Long L, Huang G, Zhu H, Guo Y, Liu Y, Huo J. Downregulation of miR-138 promotes colorectal cancer metastasis via directly targeting TWIST2. Journal of translational medicine. 2013; 11:275.

25. Karwacz K, Arce F, Bricogne C, Kochan G, Escors D. PD-L1 co-stimulation, ligand-induced TCR down-modulation and anti-tumor immunotherapy. Oncoimmunology. 2012; 1:86-88.

26. Peng W, Lizee G, Hwu P. Blockade of the PD-1 pathway enhances the efficacy of adoptive cell therapy against cancer. Oncoimmunology. 2013;2:e22691.

27. Schalper KA. PD-L1 expression and tumor-infiltrating lymphocytes: Revisiting the antitumor immune response potential in breast cancer. Oncoimmunology. 2014;3:e29288.

28. Zitvogel L, Kroemer G. Targeting PD-1/PD-L1 interactions for cancer immunotherapy. Oncoimmunology. 2012; $1: 1223-25$.

29. Soria JC, Marabelle A, Brahmer JR, Gettinger S. Immune checkpoint modulation for non-small cell lung cancer. Clinical cancer research. 2015; 21:2256-62.

30. Topalian SL, Drake CG, Pardoll DM. Immune checkpoint blockade: a common denominator approach to cancer therapy. Cancer cell. 2015; 27:450-61.

31. Sui X, Ma J, Han W, Wang X, Fang Y, Li D, Pan H, Zhang $\mathrm{L}$. The anticancer immune response of anti-PD-1/PD-L1 and the genetic determinants of response to anti-PD-1/ PD-L1 antibodies in cancer patients. Oncotarget. 2015; 6:19393-404. doi: 10.18632/oncotarget.5107.

32. Zandberg DP, Strome SE. The role of the PD-L1:PD-1 pathway in squamous cell carcinoma of the head and neck. Oral oncology. 2014; 50:627-32.

33. Shi SJ, Wang LJ, Wang GD, Guo ZY, Wei M, Meng YL, Yang AG, Wen WH. B7-H1 expression is associated with poor prognosis in colorectal carcinoma and regulates the proliferation and invasion of HCT116 colorectal cancer cells. PloS one. 2013;8:e76012.

34. Qin T, Zeng YD, Qin G, Xu F, Lu JB, Fang WF, Xue C, Zhan JH, Zhang XK, Zheng QF, Peng RJ, Yuan ZY, Zhang L, et al. High PD-L1 expression was associated with poor prognosis in 870 Chinese patients with breast cancer. Oncotarget. 2015; 6:33972-81. doi: 10.18632/ oncotarget.5583.

35. Tang Y, Fang W, Zhang Y, Hong S, Kang S, Yan Y, Chen N, Zhan J, He X, Qin T, Li G, Tang W, Peng P, et al. The association between PD-L1 and EGFR status and the prognostic value of PD-L1 in advanced non-small cell lung cancer patients treated with EGFR-TKIs. Oncotarget. 2015; 6:14209-19. doi: 10.18632/oncotarget.3694.

36. Bartel DP. MicroRNAs: target recognition and regulatory functions. Cell. 2009; 136:215-233.

37. Yeh YM, Chuang CM, Chao KC, Wang LH. MicroRNA-138 suppresses ovarian cancer cell invasion and metastasis by targeting SOX4 and HIF-1alpha. International journal of cancer. 2013; 133:867-78.

38. Jin Y, Chen D, Cabay RJ, Wang A, Crowe DL, Zhou X. Role of microRNA-138 as a potential tumor suppressor in head and neck squamous cell carcinoma. International review of cell and molecular biology. 2013; 303:357-85.

39. Liu X, Jiang L, Wang A, Yu J, Shi F, Zhou X. MicroRNA-138 suppresses invasion and promotes apoptosis in head and neck squamous cell carcinoma cell lines. Cancer letters. 2009; 286:217-22.

40. Liu X, Lv XB, Wang XP, Sang Y, Xu S, Hu K, Wu M, Liang Y, Liu P, Tang J, Lu WH, Feng QS, Chen LZ, et al. MiR-138 suppressed nasopharyngeal carcinoma growth and tumorigenesis by targeting the CCND1 oncogene. Cell cycle. 2012; 11:2495-506.

41. Yu C, Wang M, Li Z, Xiao J, Peng F, Guo X, Deng Y, Jiang J, Sun C. MicroRNA-138-5p regulates pancreatic cancer cell growth through targeting FOXC1. Cellular oncology. 2015; 38:173-81.

42. Badoual C, Hans S, Merillon N, Van Ryswick C, Ravel P, Benhamouda N, Levionnois E, Nizard M, Si-Mohamed A, Besnier N, Gey A, Rotem-Yehudar R, Pere H, et al. PD-1-expressing tumor-infiltrating $\mathrm{T}$ cells are a favorable prognostic biomarker in HPV-associated head and neck cancer. Cancer research. 2013; 73:128-38.

43. Droeser RA, Hirt C, Viehl CT, Frey DM, Nebiker C, Huber X, Zlobec I, Eppenberger-Castori S, Tzankov A, Rosso R, Zuber M, Muraro MG, Amicarella F, et al. Clinical impact of programmed cell death ligand 1 expression in colorectal cancer. European journal of cancer. 2013; 49:2233-42.

44. Konishi J, Yamazaki K, Azuma M, Kinoshita I, DosakaAkita H, Nishimura M. B7-H1 expression on non-small cell lung cancer cells and its relationship with tumor-infiltrating lymphocytes and their PD-1 expression. Clinical cancer research. 2004; 10:5094-100.

45. Ohigashi Y, Sho M, Yamada Y, Tsurui Y, Hamada K, Ikeda N, Mizuno T, Yoriki R, Kashizuka H, Yane K, Tsushima F, Otsuki N, Yagita H, et al. Clinical significance of programmed death-1 ligand-1 and programmed death-1 ligand-2 expression in human esophageal cancer. Clinical cancer research. 2005; 11:2947-53.

46. Kim ST, Ha SY, Lee S, Ahn S, Lee J, Park SH, Park JO, Lim HY, Kang WK, Kim KM, Park YS. The Impact of PD-L1 Expression in Patients with Metastatic GEP-NETs. Journal of Cancer. 2016; 7:484-89.

47. Barrett MT, Anderson KS, Lenkiewicz E, Andreozzi M, Cunliffe HE, Klassen CL, Dueck AC, McCullough AE, Reddy SK, Ramanathan RK, Northfelt DW, Pockaj BA. Genomic amplification of 9p24.1 targeting JAK2, PD-L1, and PD-L2 is enriched in high-risk triple negative breast cancer. Oncotarget. 2015; 6:26483-93. doi: 10.18632/ oncotarget.4494. 
48. Gatalica Z, Snyder C, Maney T, Ghazalpour A, Holterman DA, Xiao N, Overberg P, Rose I, Basu GD, Vranic S, Lynch HT, Von Hoff DD, Hamid O. Programmed cell death 1 (PD-1) and its ligand (PD-L1) in common cancers and their correlation with molecular cancer type. Cancer epidemiology, biomarkers \& prevention: a publication of the American Association for Cancer Research, cosponsored by the American Society of Preventive Oncology. 2014; 23:2965-70.

49. Darb-Esfahani S, Kunze CA, Kulbe H, Sehouli J, Wienert S, Lindner J, Budczies J, Bockmayr M, Dietel M, Denkert C, Braicu I, Johrens K. Prognostic impact of programmed cell death-1 (PD-1) and PD-ligand 1 (PD-L1) expression in cancer cells and tumor-infiltrating lymphocytes in ovarian high grade serous carcinoma. Oncotarget. 2016; 7:1486-99. doi: 10.18632/oncotarget.6429

50. Llosa NJ, Cruise M, Tam A, Wicks EC, Hechenbleikner EM, Taube JM, Blosser RL, Fan H, Wang H, Luber BS, Zhang M, Papadopoulos N, Kinzler KW, et al. The vigorous immune microenvironment of microsatellite instable colon cancer is balanced by multiple counter-inhibitory checkpoints. Cancer discovery. 2015; 5:43-51.

51. Rosty C, Williamson EJ, Clendenning M, Walters RJ, Walsh MD, Win AK, Jenkins MA, Hopper JL, Winship I, Southey MC, Giles GG, English DR, Buchanan DD. Re: Microsatellite instability and BRAF mutation testing in colorectal cancer prognostication. Journal of the National Cancer Institute. 2014;106.
52. Lochhead P, Kuchiba A, Imamura Y, Liao X, Yamauchi M, Nishihara R, Qian ZR, Morikawa T, Shen J, Meyerhardt JA, Fuchs CS, Ogino S. Microsatellite instability and BRAF mutation testing in colorectal cancer prognostication. Journal of the National Cancer Institute. 2013; 105:1151-56.

53. Yu H, Lu J, Zuo L, Yan Q, Yu Z, Li X, Huang J, Zhao L, Tang H, Luo Z, Liao Q, Zeng Z, Zhang J, et al. EpsteinBarr virus downregulates microRNA 203 through the oncoprotein latent membrane protein 1: a contribution to increased tumor incidence in epithelial cells. Journal of virology. 2012; 86:3088-99.

54. Breton G, Yassine-Diab B, Cohn L, Boulassel MR, Routy JP, Sekaly RP, Steinman RM. siRNA knockdown of PD-L1 and PD-L2 in monocyte-derived dendritic cells only modestly improves proliferative responses to Gag by CD8(+) T cells from HIV-1-infected individuals. Journal of clinical immunology. 2009; 29:637-45.

55. Chen Z, Liu S, Tian L, Wu M, Ai F, Tang W, Zhao L, Ding J, Zhang L, Tang A. miR-124 and miR-506 inhibit colorectal cancer progression by targeting DNMT3B and DNMT1. Oncotarget. 2015; 6:38139-50. doi: 10.18632/ oncotarget.5709.

56. Rhodes A, Jasani B, Barnes DM, Bobrow LG, Miller KD. Reliability of immunohistochemical demonstration of oestrogen receptors in routine practice: interlaboratory variance in the sensitivity of detection and evaluation of scoring systems. Journal of clinical pathology. 2000; $53: 125-30$ 